\title{
Budget numbers for US science looking up
}

\section{Big boosts for climate and basic research in President Barack Obama's proposed spending for next year.}

In the midst of the worst economic climate since the Great Depression, and with the university sector under increasing pressure (see page 14), US federal science funding is set to soar to levels that have never been seen before.

A \$3.6-trillion budget for fiscal year 2010, unveiled by President Barack Obama on 26 February, underscores the administration's stated priorities in health care, energy and education. But it also outlines big increases for most US science agencies (see graph), and notes that investment in physical-science and engineering research, as a share of gross domestic product, has dropped by half since 1970 .

The president's proposed budget must be followed up in coming months by congressional action. It comes as lawmakers are completing a budget for fiscal year 2009, a \$410-billion 'omnibus' spending bill that would finalize funds for the 12-month period that began on 1 October 2008.

Along with the billions of dollars poured into science through the recent economic stimulus package, the two budgets taken together mean that the 2007 America COMPETES Act which called for a doubling of funding at agencies including the National Science Foundation (NSF) and the Department of Energy's Office of Science - is beginning to be realized.

"It reflects a recognition on the part of this administration that science has a major role in the long-term recovery of the country," says Robert Berdahl, president of the Association of American Universities in Washington DC.

The House of Representatives passed its version of the omnibus bill last week. As Nature went to press, the Senate was expected to take

\section{US SCIENCE FUNDING ON THE RISE}

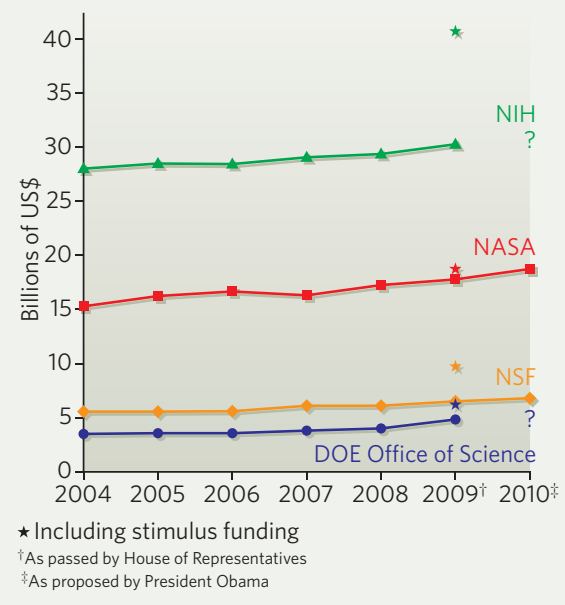

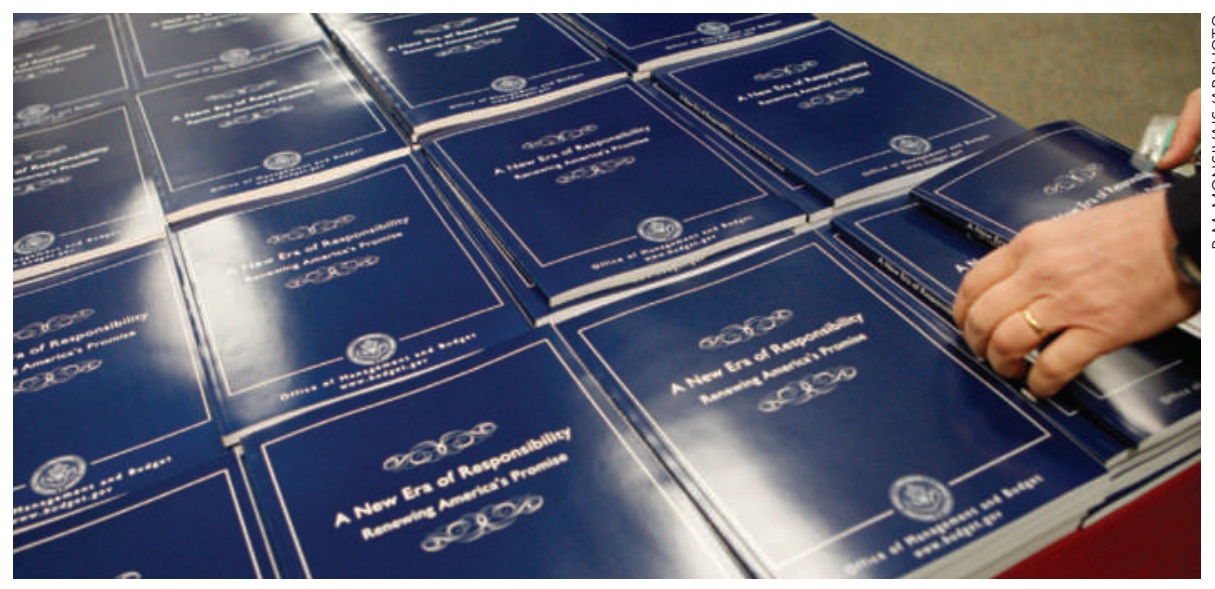

Budget bonanza: agencies such as the National Science Foundation could win big in 2010.

it up and send it to Obama to sign before a temporary funding bill expires on 6 March.

With more detailed numbers expected in April, the Obama budget released last week is a relatively thin outline with numbers assigned mainly for top-tier departments.

The budget is as much a catalogue of the administration's political agenda as it is an exercise in bean-counting, with one section entitled 'Inheriting a Legacy of Misplaced Priorities'. For example, the budget of the Environmental Protection Agency, which has languished since 2004 under the administration of George W. Bush, would receive a boost to $\$ 10.5$ billion, a jump of a third from expected 2009 levels. Yucca Mountain, the controversial long-term nuclear-waste storage facility in Nevada, would have its funding slashed (see Editorial, page 8). And a telling new source of revenue appears in the ledgers: the budget presumes that, after Congress establishes a functioning cap-and-trade agreement to control carbon emissions, $\$ 80$ billion will be raised every year, beginning in 2012.

John Marburger, who was the presidential science adviser under Bush, says that the budget proposals look very good for science. "While they reflect the energy and environment priorities of the new administration, they also address other science areas in a reasonable way," he told Nature.

The main science-funding agencies all see an upwards trajectory. NASA's budget would rise to $\$ 18.7$ billion from $\$ 17.8$ billion in 2009, with a suggestion that its focus would be as much on Earth as on the heavens: aeronautics spending would be stressed in an effort to improve air transportation, and there would be an emphasis on global climatemonitoring missions. The National Oceanic and Atmospheric Administration would also receive $\$ 1.3$ billion specifically for weather satellites and climate sensors.

The Department of Energy would settle at a budget of $\$ 26.3$ billion after spending nearly $\$ 73$ billion allotted in 2009 by the omnibus and stimulus packages. Its Office of Science, which funds foundational physics research, would get $\$ 4.8$ billion in the 2009 budget, up from $\$ 4$ billion, while the 2010 budget says only that it will get "substantially increased support".

The NSF, which got a \$3-billion infusion in the stimulus, would see its budget rise by almost $\$ 1$ billion in two years, to $\$ 7$ billion for fiscal year 2010 .

For the National Institutes of Health (NIH), the numbers in Obama's proposal are vague to non-existent; there is no specific top-line number outlined for the agency. The document does emphasize the support of cancer research at the NIH, vowing to include "over $\$ 6$ billion" to "begin the doubling of funding for cancer research". In 2008, total NIH cancer spending was $\$ 5.57$ billion.

In the congressional bill finalizing 2009 spending levels, the NIH would receive a \$938-million increase on its 2008 budget, bringing it to $\$ 30.3$ billion in 2009 . That comes on the heels of $\$ 10.4$ billion in the stimulus package. Agency officials have given only the broadest sketch of how that money will be spent (see Nature 457, 942-945; 2009).

Eric Hand and Meredith Wadman 